\title{
Qualidade Microbiológica de Carnes de Frango e Produtos A Base de Carne de Frango Analisados no Laboratório de Controle de Qualidade de Alimentos da Faculdade de Farmácia, UFG.
}

Ana Carolina Cabral Carvalhaes Costa (I), Fernanda Alves Teixeira (I), Patrícia Nasser Issy (I), Carmen Lúcia Souza (I), Fernanda Garrote Marques (I), Virgínia Farias Alves (I)

(I) FF/UFG - Faculdade de Farmácia, Universidade Federal de Goiás (Avenida Universitária, Esquina com 1ํㅡㄹ Avenida, Setor Universitário, Goiânia, GO)

\section{Resumo}

No Brasil, de 2000 a 2013, 4,58\% dos surtos de doenças transmitidas por alimentos (DTA) com causa identificada, estavam relacionados à carne de frango. De acordo com a RDC n ${ }^{\circ} 12 / 2001$ da ANVISA, para carnes resfriadas ou congeladas in natura de aves (carcaças inteiras, fracionadas ou cortes) apenas a pesquisa de coliformes a $45^{\circ} \mathrm{C}$ (termotolerantes) é obrigatória. O presente estudo objetivou fazer um levantamento sobre a qualidade microbiológica de carnes de frango e alimentos à base de carne de frango, encaminhados por demanda espontânea ao Laboratório de Controle de Qualidade de Alimentos da Faculdade de Farmácia da Universidade Federal de Goiás, entre janeiro de 2011 e março de 2014. As análises microbiológicas foram realizadas de acordo com a solicitação dos clientes e incluíram pesquisa de coliformes totais (CT) e termotolerantes (CTT) e Salmonella sp. Durante o período do estudo, 430 amostras de alimentos foram avaliadas, sendo que $39 \%$ dos produtos corresponderam a carne de frango em pedaços diversos, $28 \%$ a filé de frango, $16 \%$ a frango inteiro, $6 \%$ miúdos, $4 \%$ linguiça, todos esses crus, e cerca de $7 \%$ de alimentos preparados à base de frango (sanduíches com patê, coxinha, empada, etc.). De todas as amostras avaliadas, apenas uma $(0,23 \%)$ estava em desacordo com a RDC 12. A presença de CTT em alimentos pode

\footnotetext{
Referência:

Ana Carolina Cabral Carvalhaes Costa, Fernanda Alves Teixeira, Patrícia Nasser Issy, Carmen Lúcia Souza, Fernanda Garrote Marques, Virgínia Farias Alves. Qualidade Microbiológica de Carnes de Frango e Produtos A Base de Carne de Frango Analisados no Laboratório de Controle de Qualidade de Alimentos da Faculdade de Farmácia, Ufg.. In: Anais do $12^{\circ}$ Congresso Latinoamericano de Microbiologia e Higiene de Alimentos - MICROAL 2014 [= Blucher Food Science Proceedings, num.1, vol.1]. São Paulo: Editora Blucher, 2014. DOI $10.5151 /$ foodsci-microal-153
} 
indicar contaminação de origem fecal e/ou condições higiênico-sanitárias insatisfatórias de processamento, enquanto a presença de CT, não exigida para carne de frango pela RDC 12, é considerada uma indicação útil de contaminação pós-sanitização ou pós-processamento e de práticas de higiene e sanitização inadequadas. Mesmo não sendo exigida pela legislação a pesquisa de Salmonella sp em carne de frango crua e miúdos de frango, cerca de $90 \%$ dos clientes solicitaram essa análise. Entretanto o micro-organismo não foi encontrado em nenhum dos produtos avaliados. $\mathrm{O}$ baixo número de amostras em desacordo com a legislação vigente pode se dar pelo fato de as mesmas terem sido encaminhadas ao laboratório sob livre demanda. Dessa forma, esses resultados podem não refletir a real situação dos produtos disponíveis aos consumidores no comércio varejista, uma vez que as carcaças de aves oferecem substrato adequado à multiplicação tanto de micro-organismos deteriorantes quanto patogênicos.

Palavras-Chave: Doenças Transmitidas por Alimentos, carne de frango, qualidade microbiológica

Agência de Fomento: Nenhuma agência 